Revista Bioética

\title{
PESQUISA
}

\section{Attitudes towards physician-assisted suicide and euthanasia in Spanish university students}

María Sol Rodríguez-Calvo ${ }^{1}$, José Luis Soto ${ }^{1}$, Isabel María Martínez-Silva ${ }^{2}$, Fernando Vázquez-Portomeñe ${ }^{1}$, José Ignacio Muñoz-Barús ${ }^{1}$

1. University of Santiago de Compostela (USC), Santiago de Compostela, Espanha 2. University of Vigo (UVigo), Vigo, Espanha.

\begin{abstract}
Attitudes toward physician-assisted death among medical students differ between populations. The aim of this study was to explore attitudes towards euthanasia and physician-assisted suicide among Spanish university students. A cross-sectional survey was conducted by asking undergraduate students (Medicine, Nursing and Law) of the University of Santiago de Compostela to complete an anonymous 17-item questionnaire. Most participants exhibited a positive attitude towards physician-assisted suicide (54\%) and euthanasia (75\%), as well as towards their legalization. Attitudes were consistent with the underlying ethical reasoning, with no differences in terms of age, gender or academic degree. In addition, consistency was found between attitudes and willingness to participate in physician-assisted suicide and euthanasia, should they be legal. The results showed that the attitudes of medical students towards euthanasia and physician-assisted suicide were positive and similar to non-medical students. Keywords: Bioethics. Students. Physicians. Suicide, assisted. Euthanasia. Death. Attitude. Behavior.
\end{abstract}

\section{Resumo}

Atitudes em relação a eutanásia e suicídio medicamente assistido em estudantes universitários espanhóis

A atitude dos estudantes de medicina ante a morte medicamente assistida difere entre populações. $O$ objetivo deste estudo foi explorar as atitudes para a eutanásia e o suicídio medicamente assistido em estudantes universitários espanhóis. Foi realizada uma pesquisa transversal em estudantes de graduação (medicina, enfermagem e direito) da Universidade de Santiago de Compostela que completaram um questionário anônimo de 17 perguntas. A maioria dos participantes mostrou atitude positiva para o suicídio medicamente assistido $(54 \%)$ e a eutanásia $(75 \%)$, bem como para a sua legalização. As atitudes foram coerentes com os argumentos éticos, não encontrando diferenças em relação a idade, sexo ou titulação. Assim mesmo, as atitudes estavam de acordo com a intenção de participar nestes procedimentos, se fossem legais. Os resultados mostram que a atitude dos estudantes de medicina para a eutanásia e o suicídio assistido é positiva e similar à de estudantes de enfermagem e direito.

Palavras-chave: Bioética. Estudantes. Médicos. Suicídio assistido. Eutanásia. Morte. Atitude. Comportamento.

\section{Resumen}

\section{Actitudes hacia la eutanasia y el suicidio medicamente asistido en estudiantes universitarios españoles}

La actitud de los estudiantes de Medicina ante a la muerte médicamente asistida difiere entre poblaciones. El objetivo de este estudio ha sido explorar las actitudes hacia la eutanasia y el suicidio médicamente asistido en estudiantes universitarios españoles. Se realizó una encuesta transversal en estudiantes de grado (Medicina, Enfermería y Derecho) de la Universidad de Santiago de Compostela que completaron un cuestionario anónimo de 17 preguntas. La mayoría de los participantes mostraron una actitud positiva hacia el suicidio médicamente asistido (54\%) y la eutanasia (75\%), así como hacia su legalización. Las actitudes fueron coherentes con los argumentos éticos, no encontrando diferencias en relación con la edad, el sexo o la titulación. Asimismo, las actitudes estaban de acuerdo con la intención de participar en estos procedimientos, si fueran legales. Los resultados muestran que la actitud de los estudiantes de medicina hacia la eutanasia y el suicidio asistido es positiva y similar a la de estudiantes de enfermería y derecho.

Palabras clave: Bioética. Estudiantes. Médicos. Suicidio asistido. Eutanasia. Muerte. Actitud. Conducta.

Declaram não haver conflito de interesse. 
Euthanasia (E) and physician-assisted suicide (PAS) continue to be controversial bioethical issues among healthcare professionals. Discussions about the appropriateness of these procedures are complex due to the many aspects involved, which include ethical, legal, religious, social and psychological considerations. Euthanasia refers to the deliberate and active ending of life by another person at the explicit request of patients who are suffering from an incurable condition they deem unbearable. The term PAS is used when a physician intentionally assists a patient to end his or her life.

Recent studies have revealed a growing acceptance of these practices ${ }^{1}$, mainly attributed to the increased value given to the autonomy of the individual, together with the declining impact of religious convictions ${ }^{2,3}$. Euthanasia was legalized in three European countries, namely Belgium ${ }^{4}$ and the Netherlands ${ }^{5}$ in 2002 and Luxembourg ${ }^{6}$ in 2009. In all three countries the decision to end a life on request is based on the patient-doctor relationship. Patients must be in a condition of unsupportable and irreversible suffering.

On February 13rd, 2014, Belgium extended the possibility of euthanasia to terminally ill children, with no age limit. In the Netherlands, assisted dying is allowed for minors older than 12 years old, but parental consent is required for all persons under the age of 16 . In addition to the Netherlands and Luxembourg, Switzerland has established legal possibilities for assisted suicide. Article 115 of the Swiss Penal Code condones assisting suicide for altruistic reasons, although euthanasia is forbidden. The Swiss model differs from others in one major respect, however, in that a physician-patient relationship is not required.

In the USA, there currently exist legally sanctioned possibilities for assisted suicide in the states of Oregon, Washington, Vermont and California ${ }^{7-9}$, with initiatives in other states, such as Montana ${ }^{10}$. Dignity acts and court rulings from these states declare that patients must have a terminal physical illness. On June $5^{\text {th }} 2014$, Quebec became the first North American jurisdiction to legalize euthanasia ${ }^{11}$. In February $6^{\text {th }} 2015$, the Supreme Court of Canada struck down ban on assisted suicide in a unanimous decision ${ }^{12}$. Intense debates are currently underway in many other countries regarding the legalization of physicianassisted death (E and PAS) ${ }^{13}$.

In Spain, Law 41/2002 (the Patient's Autonomy Law) ${ }^{14}$, an act rooted in respect for the dignity of the person, reinforced the right of competent adults to refuse any medical treatment even if such refusal results in their death. Nevertheless, euthanasia and physician-assisted suicide are, at present, illegal, punishable criminal acts.

Many studies have described the attitudes of physicians and the general public toward euthanasia and PAS, revealing that over $60 \%$ of the general public find euthanasia and PAS ethical in certain circumstances ${ }^{15,16}$, although the majority of physicians do not find these practices ethical and do not support its legalization ${ }^{17,18}$. However, available data in this area in relation to medical students are limited and contradictory. In the USA ${ }^{19,20}$, the Netherlands ${ }^{21}$, Hungary ${ }^{22}$, Switzerland ${ }^{23}$, Greece ${ }^{24}$, Mexico ${ }^{25}$ and Belgium ${ }^{26}$ a majority of students were in favor of euthanasia and physician-assisted suicide. In contrast, in many other countries such as Yugoslavia ${ }^{27}$, Norway ${ }^{28,29}$, Italy ${ }^{30}$, Sweden ${ }^{31}$, Germany ${ }^{32,33}$, Austria $^{34}$, Poland ${ }^{35}$, as well as in the U.S. territory of Puerto Rico ${ }^{36}$, a negative opinion was prevalent.

Some studies reported that the views of medical students towards end-of-life decisions differ significantly from those of non-medical students ${ }^{37}$, with more permissive attitudes in the latter group 22,38 . In Spain, a survey carried out among physicians, medical students and the general public in 1992 found that most agreed with the legislation and practice of euthanasia in terminally ill patients ${ }^{39}$. To the best of our knowledge, no other surveys have been carried out since this time even though important changes have taken place in Spanish society.

The aims of the present study were therefore to explore the views of participants towards euthanasia and physician-assisted suicide, their knowledge and opinion on the law, and their intentions to participate in these procedures if made legal, in three relevant student populations (Medicine, Nursing and Law) at the University of Santiago de Compostela/Spain.

\section{Method}

\section{Participants and data collection}

A cross-sectional survey was conducted by distributing 300 questionnaires to third-year medical, nursing and law students from the University of Santiago de Compostela, during the academic year 2015-16. A total of 245 students responded (Medicine: 72; Nursing: 74; Law: 99). The questionnaires were distributed 
and collected at the beginning of lectures. In compliance with the ethical principles of research, all participants received information about the aim of the investigation, their participation was entirely voluntary and anonymity was guaranteed. No identifying information was requested and no class credits were obtained for answering.

\section{Questionnaire}

The questionnaire was prepared taking into consideration different international studies on attitudes towards physician-assisted death $17,20,22,31,34,40$. It was piloted on a small group of students (12) and then further refined. Definitions of the terms "euthanasia" and "physician-assisted suicide" were provided at the top of each survey form in order to avoid confusion.

The questionnaire consisted of 17 items and required about eight minutes to complete. It was divided into four sections: a) demographic data: age, gender, study program, and a question about the respondent's opinion on the importance of Ethics in the curriculum of health professions; $b$ ) the attitudes of participants towards PAS and E and their ethical rationale; c) knowledge and opinion about the law and d) willingness to participate in PAS and $E$ if made legal.

In section $B$ of the questionnaire students were asked to specify their strength of agreement with PAS and E "What is your view about PAS/E?", with two statements: "I think people should be able to freely decide their own death"; "It should be accepted that another person can help someone to die if asked", relating to three ethical arguments: 1) "life is a value superior to the autonomy of the person"; 2) "respecting autonomy is superior to life"; 3) "life and autonomy are values that merit respect and have to be contextualized". A five-point scale was used, with response options ranging from "strongly agree" to "strongly disagree". The answers were scored from 1 to 5 , respectively.

In section $C$, students were asked if they knew the law through the question "do you know the current law concerning PAS and euthanasia?" Answer to this question was dichotomous (Yes/ No). Those who responded affirmatively were asked about their opinions about the law using a fivepoint scale. In section $D$, students were asked about their intentions and willingness to be involved in PAS and euthanasia, also using a five-point scale. Responses to questions included in $B, C$ and $D$ were transformed from a five-point to a three-point scale for association analysis.

\section{Data analysis}

Univariate analysis and frequency distributions were used to describe the overall pattern of responses. Association analysis was carried out using $\chi 2$ for categorical data. Continuous data were analyzed using analysis of variance (Anova). A $p$-value of $5 \%$ or lower was considered to be statistically significant.

To assess whether the beliefs of students concerning ethical issues and their willingness to participate in PAS and E correlated with their selfrated categorization (in favor or against PAS and E), two indices were calculated. The ethical index was created by combining student' data on the three questions from section $B$ related to ethical arguments. Answers were scored from 1 to 5 . Scores were inverted for those questions where an answer of 5 would correspond to a pro-PAS or pro-E view. The total score ranged from 3-15, with 3 reflecting a strongly pro-PAS/pro-E view. The behavior index was obtained by the sum of scores to questions related to participation in PAS or E. The total score ranged from 2 to 10. The lower the score the more pro-PAS/ pro-E the behavior index was considered to be. Data were analyzed using the R software ( $R$ Development Core Team, version 2.11.1) ${ }^{41}$.

\section{Results}

Of 300 questionnaires, 245 were returned (response rate $82 \%$ ). Some records were excluded from certain parts of the analysis due to insufficient information.

\section{Characteristics of students and personal views towards PAS and Euthanasia}

The demographic characteristics of the sample are shown in table 1 . The majority of the students were women (73\%), 59\% attending medical or nursing studies and $41 \%$ law studies. No significant differences were found between disciplines in terms of age or gender. A large percentage of students (95\%) considered ethics an important subject in the health sciences curriculum.

Of all students sampled, $54 \%$ had a positive attitude towards PAS and $75 \%$ had a positive attitude towards euthanasia (table 1). There were no significant differences in self-categorization, either in relation to gender or with regards to age or program of study. 
Table 1. Characteristics of participants and their opinion about physician-assisted suicide and euthanasia

\begin{tabular}{|c|c|c|c|c|}
\hline \multirow[b]{2}{*}{ Variable } & \multirow[b]{2}{*}{$\begin{array}{c}\text { Total } \\
n=245\end{array}$} & \multicolumn{3}{|c|}{ Program of study } \\
\hline & & $\begin{array}{c}\text { Medicine } \\
n=72(29 \%)\end{array}$ & $\begin{array}{c}\text { Nursing } \\
n=74(30 \%)\end{array}$ & $\begin{array}{c}\text { Law } \\
n=99(41 \%)\end{array}$ \\
\hline Mean age (years, $S D$ ) & $22.5(4.2)$ & $21.64(4.67)$ & $22.21(2.97)$ & $23.85(4.78)$ \\
\hline$(\min , \max )$ & $(19-55)$ & $(19-55)$ & $(20-33)$ & $(19-47)$ \\
\hline \multicolumn{5}{|l|}{ Gender } \\
\hline Men & 27 & 26 & 23 & 30 \\
\hline Women & 73 & 74 & 77 & 70 \\
\hline \multicolumn{5}{|c|}{ Ethics is important in the Medicine and Nursing curriculum } \\
\hline Yes & 95 & 99 & 98 & 88 \\
\hline No & 1 & - & 1 & 2 \\
\hline Unsure & 4 & 1 & 1 & 10 \\
\hline \multicolumn{5}{|l|}{ Attitude towards PAS } \\
\hline Strongly agree & 28 & 31 & 23 & 31 \\
\hline Agree & 26 & 32 & 24 & 23 \\
\hline Undecided & 32 & 20 & 38 & 35 \\
\hline Disagree & 7 & 7 & 11 & 4 \\
\hline Strongly disagree & 7 & 10 & 4 & 7 \\
\hline \multicolumn{5}{|c|}{ Attitude towards Euthanasia } \\
\hline Strongly agree & 41 & 49 & 36 & 40 \\
\hline Agree & 34 & 32 & 30 & 39 \\
\hline Undecided & 16 & 12 & 23 & 13 \\
\hline Disagree & 5 & 4 & 7 & 4 \\
\hline Strongly disagree & 4 & 3 & 4 & 4 \\
\hline
\end{tabular}

Values are percentages except where indicated otherwise

Most participants (84\%) considered that people should be able to freely decide their own death. Also, a large percentage (71\%) supported the view that it should be acceptable that another person helps someone to die if asked (table 2). There was a significant correlation between attitudes towards PAS and $E$ and statements regarding freedom to decide about death and acceptance of another person helping someone to die $(p<0.001)$. Furthermore, a significant correlation was found between attitudes and ethical rationale $(p<0.001)$, and there was consistency in the answers. Most of those that supported these practices believed that respecting autonomy is superior to life, and most of those who disagreed thought that human life is more valuable.

There was a highly significant difference in the ethical index score between groups of participants $(p<0.001)$. Scores were higher among those who disagreed with PAS or E, displaying a more pro-life view and demonstrating that their attitudes are consistent with their personal beliefs. We also found that this correlation between attitudes and ethical rationale varies statistically according to degree course. Medical students had lower index scores than Law students, indicating a higher valuation of patients' autonomy (physician-assisted suicide: $p=0.002$, Coef. -0.646; euthanasia: $p=0.002$, coef. -0.638 ).

Table 2. Opinion of students about underlying arguments

\begin{tabular}{|c|c|c|c|c|c|}
\hline \multirow[b]{2}{*}{ Statement } & \multicolumn{5}{|c|}{ Students \% } \\
\hline & Response & $\begin{array}{c}\text { Total } \\
n=245\end{array}$ & $\begin{array}{c}\text { Medicine } \\
n=72\end{array}$ & $\begin{array}{c}\text { Nursing } \\
n=74\end{array}$ & $\begin{array}{l}\text { Law } \\
n=99\end{array}$ \\
\hline \multirow{3}{*}{$\begin{array}{l}\text { People should be able to decide } \\
\text { their own death }\end{array}$} & Agree & 84 & 80 & 80 & 89 \\
\hline & Neutral & 11 & 11 & 14 & 8 \\
\hline & Disagree & 5 & 9 & 6 & 3 \\
\hline \multirow{3}{*}{$\begin{array}{l}\text { An other persons help in dying } \\
\text { should be accepted }\end{array}$} & Agree & 71 & 70 & 67 & 76 \\
\hline & Neutral & 18 & 20 & 19 & 15 \\
\hline & Disagree & 11 & 10 & 14 & 9 \\
\hline
\end{tabular}


Table 2. Continuation

\begin{tabular}{|c|c|c|c|c|c|}
\hline \multirow[b]{2}{*}{ Statement } & \multicolumn{5}{|c|}{ Students \% } \\
\hline & Response & $\begin{array}{c}\text { Total } \\
\mathrm{n}=245\end{array}$ & $\begin{array}{c}\text { Medicine } \\
n=72\end{array}$ & $\begin{array}{c}\text { Nursing } \\
n=74\end{array}$ & $\begin{array}{l}\text { Law } \\
\mathrm{n}=99\end{array}$ \\
\hline \multirow{3}{*}{ Life is superior to autonomy } & Agree & 59 & 7 & 21 & 18 \\
\hline & Neutral & 25 & 18 & 26 & 30 \\
\hline & Disagree & 16 & 75 & 53 & 52 \\
\hline \multirow{3}{*}{ Autonomy is superior to life } & Agree & 54 & 71 & 47 & 47 \\
\hline & Neutral & 33 & 17 & 42 & 36 \\
\hline & Disagree & 13 & 12 & 11 & 17 \\
\hline \multirow{3}{*}{$\begin{array}{l}\text { Life and autonomy are values to } \\
\text { respect }\end{array}$} & Agree & 51 & 57 & 52 & 48 \\
\hline & \begin{tabular}{|l|} 
Neutral \\
\end{tabular} & 30 & 23 & 31 & 34 \\
\hline & Disagree & 19 & 20 & 17 & 18 \\
\hline
\end{tabular}

\section{Students' knowledge and opinion about the law}

The majority of students $(62 \%)$ responded affirmatively to the question of knowledge of the law, with $68 \%$ expressing the view that it should be changed (table 3 ). The majority of respondents supported the legalization of PAS (56\%) and, to a greater extent, of E (66\%), with no significant differences between disciplines.

A significant correlation between knowledge and opinion of the law was found $(p<0.001)$, with most respondents in favor of its modification. The attitudes of participants towards PAS and E were independent of their knowledge of the law ( $p=0.544$ and $p=0.638$, respectively). Nevertheless, a significant correlation between positive attitudes and opinions about the legalization of these practices was found $(p<0.001)$.

\section{Students' intention to participate in PAS and euthanasia}

Since personal views and behavioral trends might not be the same, participants were asked how they would act when dealing with a person seeking assistance with dying. Table 3 shows the percentage of students willing to participate in PAS and E, if these practices were legal.

A significant correlation between personal attitudes and willingness to participate in PAS and $E$ was found, and was confirmed by the behavior index $(p<0.001)$. Scores increased as participants disagreed more with these practices, indicating consistency between private views on PAS and euthanasia and predicted future behavior. No significant differences in terms of gender, age or course were found.

Table 3. Opinion of students about the law and willingness to participate in PAS and euthanasia

\begin{tabular}{|c|c|c|c|c|c|}
\hline \multirow[b]{2}{*}{ Statement } & \multicolumn{5}{|c|}{ Students \% } \\
\hline & Response & $\begin{array}{c}\text { Total } \\
n=245\end{array}$ & $\begin{array}{c}\text { Medicine } \\
n=72\end{array}$ & $\begin{array}{c}\text { Nursing } \\
n=74\end{array}$ & $\begin{array}{l}\text { Law } \\
n=99\end{array}$ \\
\hline \multirow{2}{*}{ Knowledge of the law } & No & 48 & 44 & 27 & 43 \\
\hline & Yes & 62 & 56 & 73 & 57 \\
\hline \multirow{3}{*}{ Law should be changed* } & Agree & 68 & 90 & 62 & 62 \\
\hline & Neutral & 26 & 7 & 29 & 32 \\
\hline & Disagree & 6 & 3 & 9 & 6 \\
\hline \multirow{3}{*}{ Legalization of PAS } & Agree & 56 & 56 & 58 & 53 \\
\hline & Neutral & 26 & 25 & 26 & 28 \\
\hline & Disagree & 18 & 19 & 16 & 19 \\
\hline \multirow{3}{*}{ Legalization of euthanasia } & Agree & 66 & 67 & 63 & 65 \\
\hline & Neutral & 23 & 21 & 23 & 26 \\
\hline & Disagree & 11 & 12 & 14 & 9 \\
\hline \multirow{3}{*}{$\begin{array}{l}\text { Commitment to participate in } \\
\text { physician-assisted suicide }\end{array}$} & Yes & 38 & 49 & 38 & 32 \\
\hline & Undecided & 30 & 20 & 35 & 33 \\
\hline & No & 32 & 31 & 27 & 35 \\
\hline \multirow{3}{*}{$\begin{array}{l}\text { Commitment to participate in } \\
\text { euthanasia }\end{array}$} & Yes & 48 & 60 & 46 & 42 \\
\hline & Undecided & 30 & 19 & 35 & 34 \\
\hline & No & 22 & 21 & 19 & 24 \\
\hline
\end{tabular}

\footnotetext{
*Percentages refer to students who responded affirmatively to the first question
} 


\section{Discussion}

This paper analyzed the attitudes and intentions of medical, nursing and law students towards PAS and E. An objective evaluation of the results indicates that a majority of respondents exhibited a positive attitude towards PAS (54\%) and E (75\%), which agrees with other studies carried out in the USA ${ }^{19,20}$ and Mexico ${ }^{25}$, and in some European countries such as the Netherlands ${ }^{21}$, Hungary ${ }^{22}$, Switzerland ${ }^{23}$, Greece ${ }^{24}$ and Belgium ${ }^{26}$. The cultural context, religious beliefs and personal philosophy have been found to be related to attitudes ${ }^{26,35,40,42}$. The present study revealed greater support for $E$ than PAS, which is unusual and contrasts with previously published reports. It is to be expected that helping a patient take her or his own life is more acceptable than the physician directly taking such a life.

However, people might feel safer when the hastening of the dying process is carried out by a physician. Euthanasia is a term that can cause ambivalent feelings, as the act implies two actions that appear to be contradictory: helping patients end their suffering by killing them. Negative attitudes can be explained by the fact that $E$ is intimately associated with death and even with murder. Nevertheless, this term is also related to a patient suffering from a terminal or unbearable condition who requests to die, thus evoking ideas of compassion, help, relief and choice. The positive meaning prevailed in our respondents, as reflected in their attitudes. These results are in agreement with those found in a sample of Mexican physicians and medical students ${ }^{43}$.

When the responses were analyzed by age, gender or study program, no significant associations were found. Previous findings in relation to such factors are contradictory and inconclusive; some research suggests that age affects attitudes ${ }^{39,22}$ while other studies find no age-related differences ${ }^{30,34}$. The same occurs with regards to gender; some studies report that women are more supportive ${ }^{39,21}$, while others have found men are more in favour ${ }^{22,36}$, and still others have described no differences in gender $24,28,30,34$. As for the study program, some reports ${ }^{22,37}$ demonstrated important differences in the attitudes of medical and non-medical students, the latter of whom are more supportive of the concept. Nevertheless, a recent survey on a United Kingdom university campus found no significant differences in attitude between nursing and nonnursing students ${ }^{44}$.
The vast majority of participants in this investigation consider ethics an important subject in the curriculum of Health Sciences, reflecting their view that ethics education is an important part of preparing nurses and physicians for the inevitable moral conflicts of their professional practice.

Attitudes of students towards PAS and E were consistent with opinions on the freedom to decide about death and acceptance that another person can help someone to die, and also with the underlying ethical arguments. This correlation between attitudes and ethical rationale differed according to degree, with medical students showing a greater support for patients' autonomy compared to law students. This result can reflect the utmost importance that the respect for autonomy today commands in the physician-patient relationship, which is transmitted to medical students. On the other hand, law students may be closer to the positive law, as PAS and E are banned in Spain. A previous report ${ }^{42}$ indicated that belief in autonomy was a key positive predictor of attitudes about physician-assisted suicide.

A total of $62 \%$ of the students were found to be informed about the law concerning PAS and $\mathrm{E}$. The majority believed that the law should be changed and these practices should be legalized. These results are in agreement with a previous Spanish report ${ }^{39}$ and with data from Dutch medical students ${ }^{21}$. However, in many other countries, the percentage of students with a positive opinion about the legalization of these practices was lower $22,27-33,35$. Although the attitudes of participants towards PAS and $E$ were independent of their knowledge of the law, concordance was found between personal views on assisted death and opinions about the legalization of these practices.

The present study found a significant correlation between personal attitudes and intentions to take part in PAS and E, if they were legal. Nevertheless, the percentage of respondents who were willing to participate in such practices was lower than those who declared themselves in favor of them. Even so, almost half of respondents declared their willingness to participate in $E$, and a lower proportion in PAS. These figures are clearly higher than those described in other reports ${ }^{34-36}$. This study revealed no significant differences in willingness to participate in terms of gender, age or degree course, differing from other reports ${ }^{35,36}$, which showed men were more willing to accede to a demand for PAS or E. 
The present study has some limitations that should be taken into account. Firstly, the opinions of students may change with time, implying that present intentions might not directly predict future behavior. Personal and professional experiences might change the views of respondents, as has been shown in some reports ${ }^{37,44,45}$. Secondly, the University of Santiago de Compostela may not be representative of other universities around the country. Thirdly, the fact that knowledge of the law was measured with just one question, which asks for a subjective appraisal of the respondent's knowledge, should be taken into account.

\section{Final considerations}

The results of the present study are of interest in terms of the re-opened debate on euthanasia and PAS and the progress of legalization of such practices in many countries. The majority of participants showed a positive attitude towards these practices as well as to their legalization, with no differences between medical and non-medical students.

Health care students should receive specialized education regarding end-of-life issues. In order to carry out their daily work in a safe and responsible manner, it is important that they know their professional obligations. Also, ethics education can help them to consider the wider ethical perspective when deliberating on ethical dilemmas such as those raised by patients seeking help to die, thus improving patient care.

It is suggested that the beliefs and opinions of students are tracked over time, and also compared with those of doctors and nurses. It is important to know and understand the views of health professionals on important ethical questions, such as physician-assisted death, as these issues are an integral part of their daily professional practice.

\section{Referências}

1. Cohen J, Van Landeghem P, Carpentier N, Deliens L. Different trends in euthanasia acceptance across Europe: a study of 13 Western and 10 Central and Eastern European countries, 1981-2008. Eur J Public Health [Internet]. 2013 [acesso 26 fev 2018];23(3):378-80. DOI: 10.1093/eurpub/cks186

2. Jaspers E, Lubbers M, de Graaf ND. 'Horrors of Holland': explaining attitude change towards euthanasia and homosexuals in the Netherlands, 1970-1998. Int J Public Opin Res [Internet]. 2007 [acesso 26 fev 2018];19(4):451-73. Disponível: https://bit.ly/2Z0kqQa

3. Seale C. Doctors' attitudes surveyed. BMJ [Internet]. 2009 [acesso 26 fev 2018];339:b3761. DOI: 10.1136/bmj.b3761

4. Broeckaert B. Belgium: towards a legal recognition of euthanasia. Eur J Health Law [Internet]. 2001 [acesso 26 fev 2018];8:95-107. Disponível: https://bit.ly/301oEnH

5. Janssen $A$. The new regulation of voluntary euthanasia and medically assisted suicide in the Netherlands. Int J Law Policy Family [Internet]. 2002 [acesso 26 fev 2018];16(2):260-9. Disponível: https://bit.ly/33xIUiU

6. Watson R. Luxembourg is to allow euthanasia from 1 April. BMJ [Internet]. 2009 [acesso 26 fev 2018];338:b1248. DOI: 10.1136/bmj.b1248

7. Hurst SA, Mauron A. Assisted suicide and euthanasia in Switzerland: allowing a role for nonphysicians. BMJ [Internet]. 2003 [acesso 26 fev 2018];326:271-3. DOI: 10.1136/bmj.326.7383.271

8. Dyer C. Washington follows Oregon to legalize physician-assisted suicide. BMJ [Internet]. 2008 [acesso 26 fev 2018];337:a2480. DOI: 10.1136/bmj.a2480

9. McCarthy M. Vermont governor agrees to sign bill on physician-assisted suicide. BMJ [Internet]. 2013 [acesso 26 fev 2018];346:f3210. DOI: 10.1136/bmj.f3210

10. Breitbart W. Physician-assisted suicide ruling in Montana: struggling with care of the dying, responsibility, and freedom in Big Sky Country. Palliat Support Care [Internet]. 2010 [acesso 26 fev 2018];8(1):1-6. DOI: 10.1017/S1478951509990642

11. Dyer O. Quebec to pass bill on physician-assisted suicide. BMJ [Internet]. 2014 [acesso 26 fev 2018];348:g3508. DOI: 10.1136/bmj.g3508

12. Carter v. Canada (Attorney General). Judgements of the Supreme Court of Canada [Internet]. 2015 [acesso 20 jun 2017]. Disponível: https://bit.ly/1zXx3I7

13. Steck N, Egger M, Maessen M, Reisch T, Zwahlen M. Euthanasia and assisted suicide in selected European countries and US states: systematic literature review. Med Care [Internet]. 2013 [acesso 26 fev 2018];51(10):938-44. DOI: 10.1097/MLR.0b013e3182a0f427

14. Espanha. Ley $41 / 2002$, de 14 de noviembre, básica reguladora de la autonomía del paciente y de derechos y obligaciones en materia de información y documentación clínica. Boletín Oficial del Estado [Internet]. Madrid, no 274, p. 40126-40132, 15 nov 2002 [acesso 26 fev 2018]. Disponível: https://bit.ly/1ksna9z

15. Wolfe J, Fairclough DL, Clarridge BR, Daniels ER, Emanuel EJ. Stability of attitudes regarding physicianassisted suicide and euthanasia among oncology patients, physicians, and the general public. J Clin Oncol [Internet]. 1999 [acesso 26 fev 2018];17:1274-9. DOI: 10.1200/JCO.1999.17.4.1274 
16. Emanuel EJ. Euthanasia and physician-assisted suicide: a review of the empirical data from the United States. Arch Intern Med [Internet]. 2002 [acesso 26 fev 2018];162(2):142-52. DOI: 10.1001/archinte.162.2.142

17. Dickinson GE, Clark D, Winslow M, Marples R. US physicians' attitudes concerning euthanasia and physician-assisted death: a systematic literature review. Mortality [Internet]. 2005 [acesso $26 \mathrm{fev}$ 2018];10(1):43-52. DOI: 10.1080/13576270500030982

18. Gielen J, Van Den Branden S, Broeckaert B. Attitudes of European physicians toward euthanasia and physician-assisted suicide: a review of the recent literature. J Palliat Care [Internet]. 2008 [acesso 26 fev 2018];24(3):173-84. Disponível: https://bit.ly/20X5BKb

19. Caralis PV, Hammond JS. Attitudes of medical students, house staff, and faculty physicians toward euthanasia and termination of life-sustaining treatment. Crit Care Med [Internet]. 1992 [acesso 26 fev 2018];20(5):683-90. Disponível: https://bit.ly/2TAljsb

20. Mangus RS, Dipiero A, Hawkins CE. Medical students' attitudes toward physician-assisted suicide. Jama [Internet]. 1999 [acesso 26 fev 2018];282(21):2080-1. DOI: 10.1001/jama.282.21.2080

21. Muller MT, Onwuteaka-Philipsen BD, Kriegsman DM, van der Wal G. Voluntary active euthanasia and doctor-assisted suicide: knowledge and attitudes of Dutch medical students. Med Educ [Internet]. 1996 [acesso 26 fev 2018];30(6):428-33. Disponível: https://bit.ly/2KNCvHL

22. Fekete $S$, Osvath $P$, Jegesy $A$. Attitudes of Hungarian students and nurses to physician-assisted suicide. J Med Ethics [Internet]. 2002 [acesso 26 fev 2018];28(2):126. DOI: 10.1136/jme.28.2.126

23. Marini MC, Neuenschwander H, Stiefel F. Attitudes towards euthanasia and physician-assisted suicide: a survey among medical students, oncology clinicians, and palliative care specialists. Palliat Support Care [Internet]. 2006 [acesso 26 fev 2018];4(3):251-5. Disponível: https://bit.ly/2N2aWgQ

24. Kontaxakis V, Paplos KG, Havaki-Kontaxaki BJ, Ferentinos P, Kontaxaki MI, Kollias CT et al. Attitudes on euthanasia and physician-assisted suicide among medical students in Athens. Psychiatriki [Internet]. 2009 [acesso 26 fev 2018];20(4):305-11. Disponível: https://bit.ly/31GSMoV

25. Loria A, Villarreal-Garza C, Sifuentes E, Lisker R. Physician-assisted death: opinions of Mexican medical students and residents. Arch Med Res [Internet]. 2013 [acesso 26 fev 2018];44(6):475-8. DOI: 10.1016/j.arcmed.2013.07.005

26. Roelands M, Van den Block L, Geurts S, Deliens L, Cohen J. Attitudes of Belgian students of medicine, philosophy, and law toward euthanasia and the conditions for its acceptance. Death Stud [Internet]. 2015 [acesso 26 fev 2018];39(3):139-50. DOI: 10.1080/07481187.2014.920433

27. Radulovic S, Mojsilovic S. Attitudes of oncologists, family doctors, medical students and lawyers to euthanasia. Support Care Cancer [Internet]. 1998 [acesso 26 fev 2018];6(4):410-5. DOI: $10.1007 / \mathrm{s} 005200050185$

28. Schioldborg P. Students' attitudes toward active euthanasia, assisted suicide and proposed amendments to the penal code. Tidsskr Nor Laegeforen [Internet]. 2000 [acesso $26 \mathrm{fev}$ 2018];120(19):2283-8. Disponível: https://bit.ly/2Z4z819

29. Nordstrand MA, Nordstrand SJ, Materstvedt LJ, Nortvedt P, Magelssen M. Medical students' attitudes towards legalisation of euthanasia and physician-assisted suicide. Tidsskr Nor Laegeforen [Internet]. 2013 [acesso 26 fev 2018];133(22):2359-63. DOI: 10.4045/tidsskr.13.0439

30. Grassi L, Agostini M, Rossin P, Magnani K. Medical students' opinions of euthanasia and physicianassisted suicide in Italy. Arch Intern Med [Internet]. 2000 [acesso 26 fev 2018];160(14):2226-7. Disponível: https://bit.ly/2MfydMN

31. Karlsson M, Strang P, Milberg A. Attitudes toward euthanasia among Swedish medical students. Palliat Med [Internet]. 2007 [acesso 26 fev 2018];21(7):615-22. DOI: 10.1177/0269216307081940

32. Schildmann J, Herrmann E, Burchardi N, Schwantes U, Vollmann J. Physician-assisted suicide: knowledge and views of fifth-year medical students in Germany. Death Stud [Internet]. 2006 [acesso 26 fev 2018];30(1):29-39. DOI: 10.1080/07481180500236693

33. Clemens KE, Klein E, Jaspers B, Klaschik E. Attitudes toward active euthanasia among medical students at two German universities. Support Care Cancer [Internet]. 2008 [acesso $26 \mathrm{fev}$ 2018];16(6):539-45. DOI: 10.1007/s00520-008-0427-z

34. Stronegger WJ, Schmölzer C, Rásky É, Freidl W. Changing attitudes towards euthanasia among medical students in Austria. J Med Ethics [Internet]. 2011 [acesso 26 fev 2018];37(4):227-9. DOI: $10.1136 /$ jme.2010.039792

35. Leppert W, Gottwald L, Majkowicz M, Kazmierczak-Lukaszewicz S, Forycka M, Cialkowska-Rysz A et al. A comparison of attitudes toward euthanasia among medical students at two Polish universities. J Cancer Educ [Internet]. 2013 [acesso 26 fev 2018];28(2):384-91. DOI: 10.1007/s13187-012-0414-4

36. Ramírez-Rivera J, Cruz J, Jaume-Anselmi F. Euthanasia, assisted suicide and end-of-life care: attitudes of students, residents and attending physicians. P R Health Sci J [Internet]. 2006 [acesso 26 fev 2018];25(4):325-9. Disponível: https://bit.ly/31D0005

37. Gruber PC, Gomersall CD, Joynt GM, Lee A, Tang PY, Young AS et al. Changes in medical students' attitudes towards end-of-life decisions across different years of medical training. J Gen Intern Med [Internet]. 2008 [acesso 26 fev 2018];23(10):1608-14. DOI: 10.1007/s11606-008-0713-y

38. Hagelin J, Nilstun T, Hau J, Carlsson H-E. Surveys on attitudes towards legislation of euthanasia: importance on question phrasing. J Med Ethics [Internet]. 2004 [acesso 26 fev 2018];30(6):521-3. DOI: $10.1136 / j m e .2002 .002543$

39. Vega Vega C, Moya Pueyo V. Attitudes towards active euthanasia and its legislation in Spain. Med Clin [Internet]. 1992 [acesso 26 fev 2018];98(14):545-8. Disponível: https://bit.ly/2YXjo7x 
40. Warner TD, Roberts LW, Smithpeter M, Rogers M, Roberts B, McCarty T et al. Uncertainty and opposition of medical students toward assisted death practices. J Pain Symptom Manage [Internet]. 2001 [acesso 26 fev 2018];22(2):657-67. DOI: 10.1016/S0885-3924(01)00314-1

41. R Project. The R Project for Statistical Computing [Internet]. [s.d.] [acesso 25 jun 2016]. Disponível: https://bit.ly/19WExR5

42. Weiss GL. Attitudes of college students about physician-assisted suicide: the influence of life experiences, religiosity, and belief in autonomy. Death Stud [Internet]. 1996 [acesso $26 \mathrm{fev}$ 2018];20(6):587-99. DOI: 10.1080/07481189608252764

43. Álvarez del Rio A, Marván ML. On euthanasia: exploring psychological meaning and attitudes in a simple of Mexican physicians and medical students. Dev World Bioeth [Internet]. 2011 [acesso 26 fev 2018];11(3):146-53. DOI: 10.1111/j.1471-8847.2011.00308.x

44. Hains CAM, Hulbert-Williams NJ. Attitudes toward euthanasia and physician-assisted suicide: a study of the multivariate effects of healthcare training, patient characteristics, religion and locus of control. J Med Ethics [Internet]. 2013 [acesso 26 fev 2018];39(11):713-6. DOI: 10.1136/medethics-2012-100729

45. Goldie J, Schwartz L, Morrison J. Students' attitudes and potential behaviour to a competent patient's request for withdrawal of treatment as they pass through a modern medical curriculum. J Med Ethics [Internet]. 2004 [acesso 26 fev 2018];30(4):371-6. Disponível: https://bit.ly/2ZYt2nv

\section{Participation of the authors}

María Sol Rodríguez-Calvo and José Ignacio Muñoz-Barús were responsible for the study and the analysis of data. José Luis Soto and Fernando Vázquez-Portomeñe took part in data collection and the entering and analysis of data. Isabel María Martínez-Silva was responsible for the analysis of statistical data. All the authors collaborated in and accepted the final version of the text.

\section{Correspondência}

María Sol Rodríguez-Calvo - University of Santiago de Compostela. Institute of Forensic Sciences. C/ San Francisco, s/n 15782. Santiago de Compostela, Espanha.

María Sol Rodríguez-Calvo - PhD - msol.rodriguez@usc.es

(iD) 0000-0001-9948-9667

José Luis Soto - PhD - joseluis.soto.ordonez@gmail.com

(iD) 0000-0003-1318-3822

Isabel María Martínez-Silva - Graduada - imartinez.uvigo@gmail.com

(iD) 0000-0002-0622-8802

Fernando Vázquez-Portomeñe - PhD - fernando.portomene@usc.es

(iD) 0000-0003-0237-0673

José Ignacio Muñoz-Barús - PhD - joseignacio.munoz.barus@usc.es

(iD) $0000-0002-4454-4670$ 


\section{Annex}

\section{Attitudes and opinions towards physician-assisted suicide and euthanasia}

Age:

Gender: M( ) F( )

Study program:

Ethics is important in Medicine and Nursing curriculum: Yes（） No（） I am not sure ( )

Euthanasia (E): The deliberate and active ending of life by another person at the explicit request of a patient who is suffering from an incurable condition deemed unbearable by him/her.

Physician-assisted suicide (PAS): The physician intentionally assists a patient to end his or her life.

\begin{tabular}{|c|c|c|c|c|c|}
\hline \multicolumn{6}{|c|}{ Participants' attitudes towards PAS and E } \\
\hline & \multicolumn{2}{|c|}{ Strongly agree } & \multicolumn{2}{|c|}{ Neutral } & $\begin{array}{l}\text { Strongly } \\
\text { disagree }\end{array}$ \\
\hline What is your view about physician-assisted suicide? & 1 & 2 & 3 & 4 & 5 \\
\hline What is your view about eutanasia? & 1 & 2 & 3 & 4 & 5 \\
\hline $\begin{array}{l}\text { I think people should be able to freely decide their own } \\
\text { death }\end{array}$ & 1 & 2 & 3 & 4 & 5 \\
\hline $\begin{array}{l}\text { It should be accepted that other person helps someone to } \\
\text { die if asked for }\end{array}$ & 1 & 2 & 3 & 4 & 5 \\
\hline \multicolumn{6}{|l|}{ My view about euthanasia/PAS is based on these arguments } \\
\hline Life is a value superior to person's autonomy & 1 & 2 & 3 & 4 & 5 \\
\hline Respect to autonomy is superior to life & 1 & 2 & 3 & 4 & 5 \\
\hline $\begin{array}{l}\text { Life and autonomy are values that merit respect and have } \\
\text { to be contextualized }\end{array}$ & 1 & 2 & 3 & 4 & 5 \\
\hline
\end{tabular}

\section{Knowledge and opinion about the law}

Do you know the current law concerning PAS and euthanasia? Yes ( ) No ( )

\begin{tabular}{|l|c|c|c|c|c|c} 
& Strongly agree & \multicolumn{3}{c|}{$\begin{array}{c}\text { Neutral } \\
\text { disagree }\end{array}$} \\
\hline I Consider that PAS/E Law should be changed & 1 & 2 & 3 & 4 & 5 \\
\hline PAS should be legalized & 1 & 2 & 3 & 4 & 5 \\
\hline Euthanasia should be legalized & 1 & 2 & 3 & 4 & 5 \\
\hline Willingness to participate in PAS and E if made legal & 1 & 2 & 3 & 4 & 5 \\
\hline I would participate in physician-assisted suicide & 1 & 2 & 3 & 4 & 5 \\
\hline I would participate in euthanasia & &
\end{tabular}




\section{Erratum}

In the article "Attitudes towards physician-assisted suicide and euthanasia in Spanish university students", doi 10.1590/1983-80422019273333, in Revista Bioética, published in volume 27, No 3, 2019, page 498:

\section{Where it reads:}

María Sol Rodríguez-Calvo - PhD - msol.rodriguez@usc.es (1) 0000-0002-6491-2784

José Luis Soto - PhD - joseluis.soto.ordonez@gmail.com (1) 0000-0003-2607-3390

\section{It should read:}

María Sol Rodríguez-Calvo - PhD - msol.rodriguez@usc.es (1) 0000-0001-9948-9667 José Luis Soto - PhD - joseluis.soto.ordonez@gmail.com (1) 0000-0003-1318-3822 